\title{
Professional Expert Communities as a Party in Socio- Economic Relations
}

\author{
Ruslan Dolzhenko ${ }^{1},{ }^{*}$ Svetlana Dolzhenko ${ }^{2}$
}

\author{
${ }^{1}$ Ural Institute of Management - a branch of RANEPA, Russia \\ ${ }^{2}$ Ural State University of Economics, Russia \\ *Email: dolzhenko-ra@ ranepa.ru
}

\begin{abstract}
The paper discusses professional expert communities' role in socio-economic relations and solving different tasks by community members. The definition of the term "professional expert community" is given with the emphasis on experts' role in such communities. The paper singles out several factors that contribute to professional expert communities' development and presents their original classification. The theoretical foundation for this research includes $\mathrm{O}$. Williamson and E. Ostrom's works, the Nobel Prize winners and prominent economists specialising in institutional economics. From the perspective of these scholars, professional expert communities must follow specific management principles and solve the problems connected with transaction costs. Moreover, community members' skills and experience are to be used altogether; institutional design principles may be affected. The study's main conclusion is that extensive development of professional expert communities may help accumulate knowledge, skills, and community members' competencies necessary to solve urgent social problems. We believe that in the future professional expert communities can be actively involved in socio-economic relations.
\end{abstract}

Keywords: Professional community, Expert community, Community management, Self-organization of people, Problem-solving.

\section{INTRODUCTION}

Nowadays, companies, governments, communities, and individuals tend to use the potential of selforganising communities in general and invite experts to solve specific problems, in particular. Professional communities were created to protect; however, at the beginning of the 21 st century, they focus on information provision and experience exchange. At present, these communities are involved in professional standards development, legislative drafts analysis, etc. In fact, professional communities are gradually being transformed into expert communities, and the main members are not representatives of some profession anymore, but specialists having the necessary knowledge, background and skills in a specific profession.

The experience of the last few years proves that business, state, society, and individuals realise the potential of professional communities and become important socio-economic relations members. E. Ostrom (Ostrom, 2000, 152) underlines the importance of communities: "Local, self-organized institutions are a significant asset in the institutional portfolio of humankind and need to survive into the twenty-first century" [1].

\section{THE NOTION AND ESSENCE OF PROFESSIONAL EXPERT COMMUNITY}

The topic of professional communities attracts much attention. However, the most cited studies on different aspects of professional communities are devoted to establishing such communities at schools through organizational learning [2] and assessing the influence of professional communities on students' achievements [3].

The role of professional communities in the sphere of personnel management is analysed in the research work of Nancy J. Adler и Susan Bartholomew [4]. This article 
highlights the idea that a professional community that unites researchers and specialists in HR management leads to knowledge accumulation used by its members. The most important aspect of the collaboration of academicians and specialists within professional communities is knowledge exchange. To share the knowledge, necessary to treat it as a common resource [5].

Contemporary academic literature often mentions the concept of "professional community" [4]. Traditionally it is interpreted as a self-regulating association of representatives of one profession who bear its values and norms. The concept has been used for quite a long time, as professional communities exist in different forms, for instance, workshop associations, guilds, unions, associations and others. Its meaning, however, is changing due to the society's transition to the postindustrial stage of development, the introduction of computer technologies in different spheres and continuous transformations of organizations. The criteria that determine belonging to a specific profession are not of primary importance anymore; it is rather necessary to be an expert in a specific field that is crucial today [6]. Experts are people who influence decision making and are responsible for their fulfilment. To this extent, the expert's activity essence is making an intuitive-logical analysis of the problem alongside the quantitative evaluation of judgments and interpretation of the results.

So, a conclusion can be drawn that professional and expert communities have differences, and they are not always parts of each other. N.A. Martyanova underlines that there are significant differences between professionals and experts: "firstly, a professional makes decisions and bears responsibility for them, while an expert performs other functions - those of analysis and consultation; secondly, an expert must transform professional knowledge into commonly-used one; an expert is an interpreter, a translator from a professional language into an everyday language" [6]. The professional community is a union of specialists in a specific professional field who communicate regularly to exchange knowledge, experience and the best practices to search for the ideas and efficient ways to solve urgent problems [7].

The object of this research is professional communities which, among all the others, perform an expert function. Thus, a new term should be introducedprofessional expert communities, which are teams of specialists in different fields working in different organizations who possess and use expert knowledge and experience in the professional field the community belongs to.

\section{CLASSIFICATION OF PROFESSIONAL EXPERT COMMUNITIES}

The features put in the bases for communities classification may be described as examples of professional communities in the sphere of $\mathrm{HR}$ management, which was analysed in one of our previous works where we studied 104 Russian professional communities of HR management [8]. In a further study, the number of communities was reduced due to the change of the research object; we focused on the communities that perform expert functions and set ambitious goals, such as:

- Facilitation of public debate and putting forward proposals to improve the legislative and regulatory frameworks of the Russian Federation in the sphere of HR management;

- Implementation of innovations in human resources policy into the operation of companies and establishments [9].

As a result of community activity analysis, we singled out 50 professional expert communities ( $48 \%$ of the total number) and classified them based on different parameters.

The first classification is based on the form of property (figure 1):

1. Formalised (having a legal status);

2. Non-formalised (having no legal status).

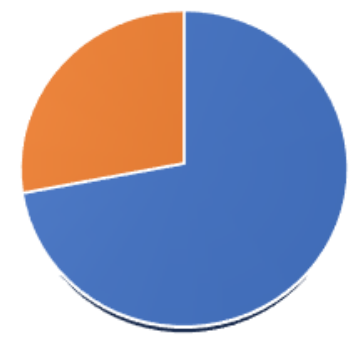

- Non-formalised community (based on consulting companies, recruitment agencies, educational establishments, Internet-communities, etc.)

" Formalised community (non-profit partnership, nonprofit organisation, public interest organisation, nongovernmental organisation)

Figure 1 HR professional expert communities based on the form of property.

$72 \%$ of communities (36 organizations) belong to the "formalised" ones; they have a legal status and, as a rule, exist in the form of non-profit organizations. This proportion is evident because it is necessary to have an account, bank details and some other official documents to perform their expert activity, especially on a commercial basis. Non-formalised communities are 
organized based on public councils, methodological councils, scientific and technical councils and others.

The second classification is based on the communication type:

1. Offline (traditional interaction without Internet communication);

2. Online (Internet-resources; job-portals that unite HR managers, provide online communication and discussion of various fields of activity in the HR sphere);

3. Mixed (include both types of communication offline and online).

According to this research, $100 \%$ of professional expert communities are either online or mixed. Today many communities prefer to work online using modern digital technologies, crowdsourcing platforms for project and tasks discussion and performing expert examination [5].

The third classification is based on the location of the community (figure 2).

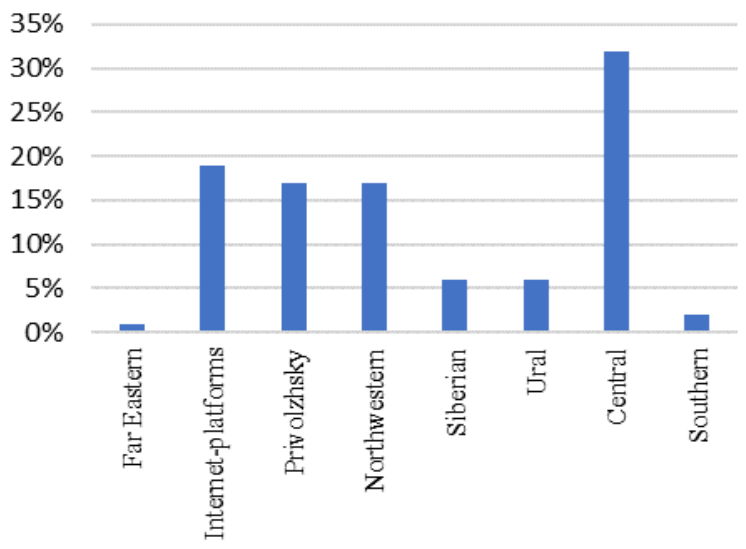

Figure 2 Communities in different regions of Russia.

Most of the communities are in the regions where the number of people working in the HR sphere is more significant, and these regions are large and welldeveloped. Among these regions are:

- Central Federal District is the home for $32 \%$ of the total number of communities;

- Internet-platforms host $19 \%$ of all HR communities under study;

- Privolzhsky and Northwestern Federal Districts include $17 \%$ of communities total number each);

The fourth classification is based on the community level:

1. International

2. National

3. Regional

4. Corporate
Corporate communities are gaining popularity, focusing on expert and project activities aimed at discussing and settlement of specific professional issues.

The fifth classification is based on the professional sphere. As mentioned above, in this research we include only professional expert communities in the HR sphere. Other spheres where such communities are established are politics, economics, medicine, jurisprudence, defence, engineering, science and education, religion, art, information technologies, etc.

\section{FACTORS OF COMMUNITIES' DEVELOPMENT AND SUCCESSFUL INTERACTION BETWEEN THEIR MEMBERS}

Before the publication of the Nobel Prize Winner E. Ostrom's research results, it was generally accepted that the problem of interaction between community members did not have an ultimate solution, at least in those cases when people were left on their own. The possible solution to the problem might be found if the state interfered in and regulated the community's work. E. Ostrom found proofs contradicting that point of view. "Her works revealed a huge number of social facts which were invisible to scholars. They revolutionised social sciences in the questions of possibilities to regulate common resources; in other words, the abilities of "ordinary" people to self-organization and self-management" [10]

Thus, E. Ostrom formulates eight general principles of institutional design, increasing the chance for success of self-organising communities. In this research, it is important to discuss those principles that can be referred to professional expert communities.

- The first principle: communities should have clearly defined boundaries. This principle clarifies who the community member is and who is not its member, who should interact and cooperate to solve a specific problem.

- The second principle: rules of the use of resource should limit its amount, time and technology; the benefits should correspond to the expenses; the local environment should be taken into account. The critical resource of professional communities is information (pool of knowledge, discussion results and information about the experts). If a community member uses the resource, they should bear expenses.

- The third principle: most resource appropriators should participate in decision-making when rules of resource usage are made or modified. This principle can be expanded: in professional expert communities, all members must participate in making decisions connected with resource use and expert discussions of different questions. V.A. Ryzhko underlines that the nature of an expert assumes variability of assessment depending on the situation. In general, the notion "expert" is post- 
modern because this person is not a monopolist in their judgments [11]. The phenomenon of the variability of judgments, which experts can make during the discussion, requires many experts to participate in discussion and assessment, which increases the relevance of judgments and the community status in general.

The factors that influence community formation and development include: 1) common goals, interests and needs of community members; 2) resources that all community members have access to; 3 ) common context and language of all community members.

The efficiency of a community is determined by the adequately designed system of motivation for experts which ensures participation of highly professional experts in the community and motivates them to achieve the best results. However, a traditional incentive system is not suitable for professional expert communities, as the community members are independent (they do not report to the head of the company), and free from prescriptive responsibilities; there is no labour contract (except for cases when independent contractor agreements are concluded). Communities are described in the following way:

- T. Naylor, W. Willimon, and R. Osterberg say: "Community can be defined as "a partnership of free people committed to the care and nurturing of each other's mind, body, heart, and soul through participatory means" [12, p. 42].

- H. Mintzberg writes that the community is "people's sense of belonging to and caring for something larger than themselves" [13, p. 140].

- K. Heller: "The conception of community that we develop must recognise its multifaceted nature and go beyond locality-based models of village and neighbourhood to include the diversity of groups which most of us identify and which give meaning to our lives" [14, p. 13].

So, the following motivational factors can be identified:

- organizational and economic factors (bonus payments, working conditions, tools and equipment and rating of experts);

- informational factors (access to unique and up-todate analytical information);

- socio-psychological factors (prominence and recognition in the professional sphere, professional growth, authority and status, achievements, independence in decision-making, a feeling of belonging to a community).

The work of a group of experts united in a professional expert community requires extra knowledge in cooperation coordination and communication improvement. It means that one more important factor influencing professional expert community development is further education and training of experts.

\section{ROLE OF A PROFESSIONAL EXPERT COMMUNITY IN SOCIO-ECONOMIC ISSUES SETTLEMENT}

Unfortunately, there is not enough empirical data about HR professional communities. The most detailed and extensive research was undertaken in the Higher School of Economics by Mersiyanova I.V. in which a group of scholars did a survey among the members of professional communities and analysed its results [15].

This research aims to assess such communities' expert potential in accomplishing the tasks set on the federal level aimed at the development of HR management as a profession. Among such tasks, we find the following: participate in development and discussion of professional standards in HR management, function as experts in the national professional contests, and others.

A survey among 50 professional expert HR communities has been carried out. Its results revealed that only 15 communities $(30 \%$ of the total number of respondents) show their readiness to function as experts in association with the Council on professional qualifications in the sphere of HR management. Among the main reasons of being unprepared for such function, according to community members' answers are the following: lack of competent experts; lack of time and financing to invite experts in communities; absence of financial benefit of expert activity. It should be mentioned that expert activity is performed free of charge.

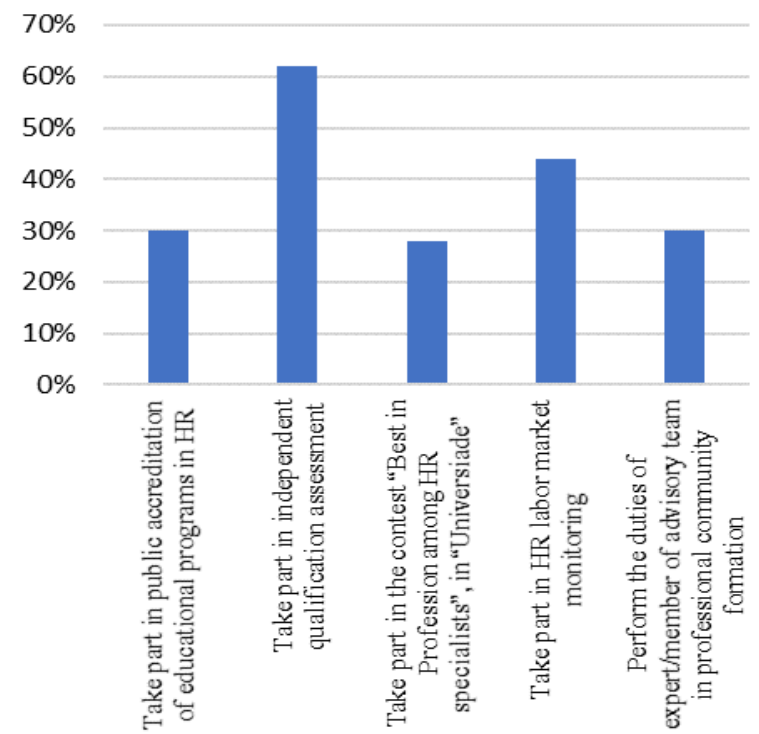

Figure 3 Areas of cooperation of professional communities with the Council on professional qualifications expertise. 
Communities that show readiness for the expert activity identified the following areas of cooperation with the Council on HR management's professional qualifications (figure 3).

The most popular areas of expert activity are:

1. Participation in the implementation of the system of qualifications' independent assessment (or performance review). Such activity is mentioned as the most attractive, as it may profit if a Centre for qualification assessment is created.

2. Participation in HR labour market monitoring. Although this work is not paid, community members are interested in it, probably because of the opportunity to access important information and statistics.

The following can be concluded: although there is an excellent need for experts to examine different issues in various spheres, communities show little interest in this work. The main reason is lack of financial benefits. This problem requires further study, and in one of the other papers, we will analyse experts' motivation in professional communities.

\section{CONCLUSION}

Evolution of professional communities in the modern world is influenced, first of all, by economic reasons, so, the study of their prospects must be done based on economics. The activity of self-organising communities is not paid. To attract experts to become members of such communities, it is necessary to continually update the scope of problems a community deals with and introduce new incentives.

There is an apparent contradiction between the potential of self-organising professional communities and their actual usage. Moreover, there are no sufficient institutional bases for cooperation between community members, between different communities and relations between communities and other parties that are not community members. The study of professional expert communities will identify their opportunities and prospects in society's life using the accumulation of knowledge, skills, and abilities to fulfil various tasks set by the state, society, other communities, companies or individuals.

\section{ACKNOWLEDGMENTS}

The reported study was funded by the Russian Foundation for Basic Research, project number 19-01000933.

\section{REFERENCES}

[1] E. Ostrom, Collective Action and the Evolution of Social Norms, Journal of Economic Perspectives Vol. 14 Iss. 3 (2000) 137-158.
[2] J.P. Scribner, K. S. Cockrell, D.H. Cockrell, J.W. Valentine, Creating professional communities in schools through organizational learning: an evaluation of a school improvement process, Educational administration quarterly Vol. 35 Iss. 1 (1999) 130-160. DOI: https://doi.org/10.1177/0013161X99351007

[3] C. Lomos, R.H. Hofman, R.J. Bosker, Professional communities and student achievement - a metaanalysis, School effectiveness and school improvement Vol. 22 Iss. 2 (2011) 121-148.

[4] N. Adler, S. Bartholomew, Academic and Professional Communities of Discourse: Generating Knowledge on Transnational Human Resource Management, Journal of International Business Studies 23 (1992) 551-569. DOI: https://doi.org/10.1057/palgrave.jibs.8490279

[5] A. Ardichvili, V. Page, T. Wentling, Motivation and barriers to participation in virtual knowledgesharing communities of practice, Journal of knowledge management 7.1 (2003) 64-77. DOI: https://doi.org/10.1108/13673270310463626

[6] N.A. Martyanova, Construction of Professional Communities: From Professional Groups to Expert Communities, News of the Herzen Russian State University for Humanities 162 (2013) 136-140.

[7] R.A. Dolzhenko, Professional communities: opportunities for building and using in the organization, Problems of economics and management of oil and gas organizations 1 (2015) 34-39.

[8] R. Dolzhenko, S. Ginieva, Use of HR professional communities in developing the system of professional qualifications, The 11th International Days of Statistics and Economics, Prague, 2017.

[9] S.B. Ginieva, A.E. Fedorova, Effective management of human resources: the way to innovative development of the region, Manager 9-10(13-14) (2010) 44-53.

[10] R.I. Kapelyushnikov, Variety of Institutional Worlds: The Nobel Prize in Economics. Part 1, M., Higher School of Economics, 2010.

[11] V.A. Ryzhko, Problems of the Culture of Humanities Expert: ZPU Iss. 4, 2006. Retrieved from Retrieved from: http://cyberleninka.ru/article/n/problemy-kulturygum

[12] T.H. Naylor, W.W. Willimon, R.V. Osterberg, The Search for Meaning in the Workplace. Abigon Press, 1996. 
[13] H. Mintzberg, Rebuilding Companies as Communities. Harvard Business Review, No. 87(7), $2009 . \quad$ Retrieved from http://hbr.org/2009/07/rebuilding-companies-ascommunities/

[14] K. Heller, The return to community, American Journal of Community Psychology 17 (1989) 1-15.

[15] I.V. Mersiyanova, A.F. Cheshkova, I.I. Krasnopolskaya, Self-organization and Problems of Professional Community Formation in Russia. Moscow, HSE, 2011, p. 188. 